\title{
A conversation with Don Ganem
}

A

fter a 15-year focus on the biology of the hepatitis B virus (HBV) family, the modern-day microbe hunter Don Ganem turned his attention to KSHV, the herpes virus that is the cause of the AIDS-related neoplasm Kaposi sarcoma (KS). His lab at UCSF was the first to cultivate and develop tests for KSHV. In 2010, after nearly 30 years in academia, Ganem (Figure 1) left for industry and is currently the Vice President and Global Head for Infectious Disease for the Novartis Institutes for Biomedical Research. The full interview, with many more stories about flunking algebra to hold hands with a girl, what martians with golf clubs can teach you about drawing conclusions, and taking a turn as Dr. Dolittle, can be seen on the JCI website, http:// www.jci.org/kiosk/cgm.

JCI: What were you like as a kid?

Ganem: I was kind of a geek as a kid. I grew up in northern Massachusetts, right on the New Hampshire border in a suburb of a grimy, industrial town called Lawrence. That area was a little microcosm of American immigration. Every single wave of immigration sent a little pseudopod into Lawrence to work in the factories there. My grandparents were some of those immigrants - from Lebanon. It was a blue-collar type setting, although my father was a surgeon. And so, we had a white-collar lifestyle in a blue-collar town.

JCI: When, during your geeky childhood, did you kindle your interest in science?

Ganem: When I got to high school, my first encounter with science was a very unhappy one. Freshman year I took something called earth science, which was a combination of geology and meteorology, and the instructor was just terrible. It was a joyless experience. The next year, I took biology and that course was spectacular. I fell in love with the subject right then and there, and I knew I couldn't get enough of it. Also, James Watson's book on the double helix was just published and my dad got it for me for Christmas. I could not put it down - I read it practically in one sitting. I fell in love with that book and with the idea of being a molecular biologist.
JCI: Did that prompt you to reach out to Watson so that you could work in his lab as an undergrad?

Ganem: No, that was an accident. I think it was the spring term of my sophomore year, and since I had taken all the undergraduate science courses at Harvard, I took the shuttle over to the medical school and took Jon Beckwith's graduate course in bacterial genetics, and I absolutely fell in

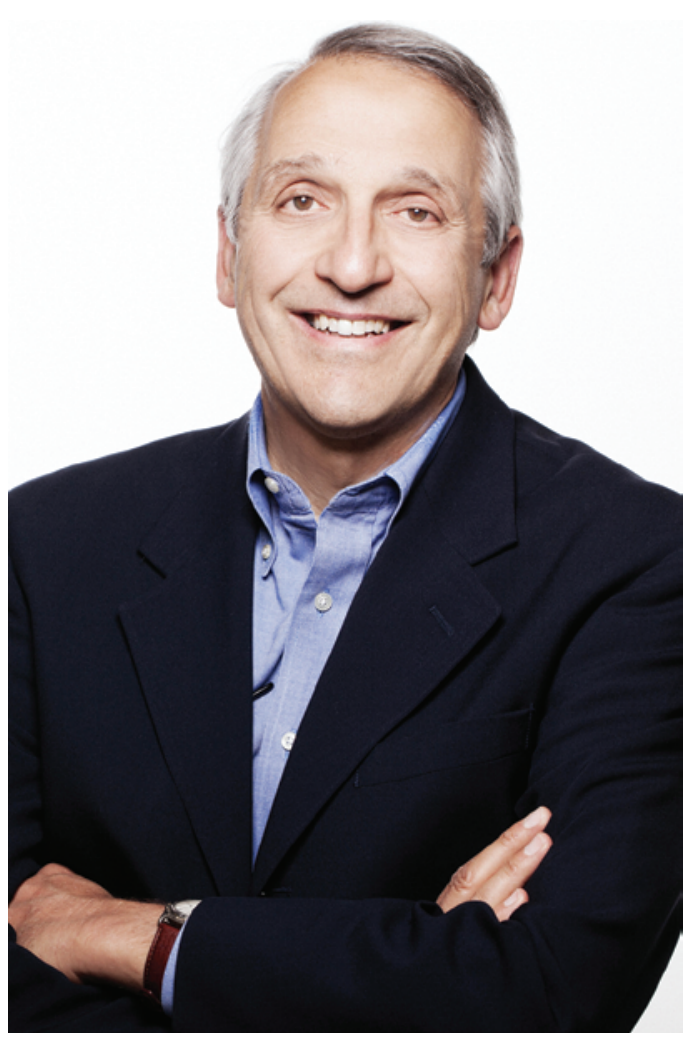

Figure 1

Don Ganem on June 21, 2013. Image credit: Alena Soboleva.

love with that subject. The summer after that course, I tried to get a job doing some sort of microbial genetics. I went to see Wally Gilbert in the bio labs and he had no time for an undergraduate but he suggested I see a young scientist named Jeffrey Miller, who worked jointly with Jon Beckwith and Jim Watson. I willy-nilly became part of what was then called the WatsonGilbert group because Jeffrey was affiliated with Jim - so I was a sort of an adoptee of the Watson group. That was a spectacular environment for a kid.

JCI: After that exposure to research, what made you decide you wanted to go to medical school?

Ganem: Being surrounded by all these brilliant people and being only 19 , I came to the conclusion that I probably wasn't smart enough for a basic research career. I began to think about whether there was a way to do something different with my molecular biology background. I knew a lot about medicine because my father was a doctor; I thought maybe this stuff was more applicable to medicine. There were potentially ways to apply all this knowledge to medicine and to infectious disease and pathogenic microorganisms. So for me, med school was all about lateralizing to learn about human biology and medicine so I could study infectious disease.

JCI: But you decided that you enjoyed patient care.

Ganem: I did the first two years of med school, and then after my second year I took a leave to work in the lab. I worked on SV40 DNA replication with George Fareed - I had a blast during those 18 months. When I went back to med school, I discovered to my surprise how much I really enjoyed the wards. I loved taking care of people; I loved the intellectual puzzle of diagnostics. I decided that the only way to be sure I could really do this job was to pick a really difficult residency. I stayed in Boston at Brigham and Women's Hospital, which was a really good residency but also known to be a hard one. I got totally bonded to clinical medicine during my years at the Brigham.

JCI: And yet you decided to do postdoctoral research.

Ganem: That was always a given, that I was not through with my science training, particularly because of all those years that had elapsed between when I worked on SV40 and when I returned to the world of science. The whole field had moved so dramatically and rapidly, and molecular biology, which had been a little specialty niche when I was a student, was now the language in which all of biology was clearly 
destined to be spoken. I decided I needed to go to a first-rate lab but this time not just as a training exercise. I needed to go somewhere where I could work on the kind of problem I wanted to work on with somebody of the caliber who could teach me and get me back up to speed to where I needed to be, and that's how I chose to go to Harold Varmus's lab.

\section{JCI: And why HBV?}

Ganem: The next problem I was going to work on had to be something having to do with human disease and it had to be from a human pathogen. It's true that I fell in love with clinical medicine but I didn't abandon the logic of my going to med school to learn about pathogens. I'd heard through the grapevine that Harold was interested in hepatitis B and I wrote to him and I asked him if there was any way that I could go there, not to work on retroviruses, but to work on HBV. And he said, "Sure." It surprises me to this day, but that's how it happened. I was the first postdoc to begin working on HBV in Harold's lab.

JCI: You then established your own HBVfocused lab as an assistant professor at UCSF after a brief return to the Brigham to serve as chief resident.

Ganem: I was lucky because I didn't really start a lab completely on my own. Harold and I had an arrangement in which I would continue to satellite around his lab. I would be the prime mover on most of the HBV projects, but he still had a couple of postdocs, and so I was starting my group in the shadow of Harold's group. I know that kind of arrangement often ends badly, but in my case it was terrific. It worked well in part because Harold is such a gentleman and a true scientist whose only interest is in science and not in self-promotion.

JCI: Why did you decide to switch to studying KSHV?

Ganem: The shift began when I was at an American Society for Virology meeting in the late 80s. The plenary sessions are always given by very senior figures and tend to be overviews of not only current research but also in the context of what's gone on before. I remember being about 40 or so at the time and at that particular meeting all of the plenary session speakers were people who had been very influential when I was in college and medical school. Many of them gave talks that were still about the very same problem that they had been working on when I was a kid. I realized that I did not want at the age of 50 to be working on the same thing I was working on when I was 37 . One of the things that I'd always wanted to do was to work on a pathogen or discover a pathogen. What I was doing with $\mathrm{HBV}$, the virus was already known and clearly linked to chronic hepatitis and hepatoma. I wasn't working on the etiologic or pathogenic problem, I was working on replication. Granted, it was a new and very different, complicated replication problem, but I had to start thinking about the next big thing. By this time the AIDS epidemic was well underway in San Francisco, and during my attending months on the ID service we were seeing a lot of HIV and a lot of KS. I remember sitting on the plane on my way home, making a list on a napkin of all the diseases that I was pretty sure were going be infectious but for which no etiology had been established. At the top of that list was KS. I still remember what number 2 was, which was Kawasaki disease. Thank God I didn't choose that because that is still an unsolved problem!

We were the first group to grow the KS virus and to see it via electron microscopy. Contemporaneously, there were 3 or 4 other groups that were working on making serologic tests, many of which involved using the cell line that we had developed. The most important thing for me was needing to be sure that this really was the agent of KS because what was known at the time was the genome was present in KS tissue, but it wasn't known what cell type it was in - and KS is a very complicated histological lesion. We had to figure out whether this was an opportunistic saprophyte, or whether this was really the cause. After doing clinical epidemiology we concluded that KSHV was the etiologic agent, because the prevalence of KSHV was superimposable on what epidemiologists had predicted the agent ought to do. It was common in people who were at risk. It was rare in people who were not at risk. It was not widely disseminated in the general population. That experience was a very addictive one as it was the first time in my 15 years on faculty when I ever did an experiment with human materials.

JCI: It always seemed to me that you were the prototypical academic physician. What made you decide that a position at Novartis was the next logical step for your career?

Ganem: I was - and I am! I couldn't imagine that I would ever retire as anything but a Professor of Medicine and Microbiology. For most of my adult life
I thought that, and I'd been offered jobs in the industry and turned them down. Mark Fishman called me about leading ID research at Novartis the week before my 60 th birthday, and I had already been wondering what the next phase in my career was going to be. I'd been on the advisory board at Novartis for about five years and I knew the organization well. I knew they had great leadership and a strong commitment to science.

Science and medicine are exactly congruent in a company, whereas in a med school you're either living in the world of scienceor you're living in the world of medicine but rarely living in both worlds simultaneously. In a company you spend all day long thinking about clinical problems at the atomic and molecular level. In my typical day I'll meet with a crystallographer, and then a clinical investigator, and then an enzymologist, a biochemist, a molecular biologist, and somebody from the protein expression group. It's all in the service of the kind of problems that I had grown to love from studying medicine. Every single thing that I learned over the 30 years at UCSF is immediately applicable to what I'm doing at Novartis.

JCI: What do you want to accomplish there in the next ten years?

Ganem: I want to make therapies. I want to produce new useful antibiotics for multi-resistant gram-negative rods. And if I have my druthers, I want them to be entirely new molecular classes - not sixth generation cephalosporins or penicillins. Obviously if we have to go down that road, we will, but the big challenge in antibacterials is there hasn't been a new chemical class for over 20 years. The quinolones were the last really novel gram-negative antibiotic, and before that were the cephalosporins. This gets to the very fundamental problem that we have an ignorance of how small molecules get across the bacterial outer membrane. I would love to systematically solve that dilemma and produce a generation of new chemical entities that can be active.

JCI: If you were not a medical doctor and a scientist, what different vocation do you think you might have chosen?

Ganem: I think I would have probably been a professor of history or maybe a diplomat. I could easily see being a diplomat, although not in an era dominated by a Republican Congress.

\section{Ushma S. Neill}

